\title{
Article \\ Original Contributions to the Chemical Composition, Microbicidal, Virulence-Arresting and Antibiotic-Enhancing Activity of Essential Oils from Four Coniferous Species
}

\author{
Diana-Carolina Visan ${ }^{1}$, Eliza Oprea ${ }^{2, * \mathbb{D}}$, Valeria Radulescu ${ }^{1}$, Ion Voiculescu ${ }^{3}$, Iovu-Adrian Biris ${ }^{3,4}$, \\ Ani Ioana $\operatorname{Cotar}^{5}{ }^{(0}$, Crina Saviuc ${ }^{6,7}$, Mariana Carmen Chifiriuc ${ }^{6,7,8}$ ) and Ioana Cristina Marinas ${ }^{6,7}$ \\ 1 Department of Organic Chemistry, Faculty of Pharmacy, University of Medicine and Pharmacy \\ "Carol Davila", 6 Traian Vuia Street, 020956 Bucharest, Romania; diana.ilies@umfcd.ro (D.-C.V.); \\ valeria_radulescu@yahoo.com (V.R.) \\ 2 Department of Organic Chemistry, Biochemistry and Catalysis, Faculty of Chemistry, University of Bucharest, \\ 4-12 Regina Elisabeta, 030018 Bucharest, Romania \\ 3 "Marin Drăcea" National Institute for Forestry Research and Development, 128 Eroilor, \\ 077190 Voluntari, Romania; ion.voiculescu@yahoo.com (I.V.); iovu.biris@gmail.com (I.-A.B.) \\ 4 Faculty of Agriculture, University of Agronomic Sciences and Veterinary Medicine of Bucharest, 59 Mărăşti, \\ 011464 Bucharest, Romania \\ 5 Cantacuzino National Medico-Military Institute for Research and Development, 103 Splaiul Independenței, \\ 050096 Bucharest, Romania; aniioana@gmail.com \\ check for \\ updates \\ Citation: Visan, D.-C.; Oprea, E.; \\ Radulescu, V.; Voiculescu, I.; \\ Biris, I.-A.; Cotar, A.I.; Saviuc, C.; \\ Chifiriuc, M.C.; Marinas, I.C. Original \\ Contributions to the Chemical \\ 6 Research Institute of the University of Bucharest-ICUB, 91-95 Spl. Independentei, \\ 050657 Bucharest, Romania; crina.saviuc@yahoo.com (C.S.); carmen.chifiriuc@unibuc.ro (M.C.C.); \\ ioana.cristina.marinas@gmail.com (I.C.M.) \\ 7 Microbiology Department, Faculty of Biology, University of Bucharest, 1-3 Portocalilor Way, \\ 060101 Bucharest, Romania \\ 8 Academy of Romanian Scientists, 3 Ilfov Street, 50044 Bucharest, Romania \\ * Correspondence: eliza.oprea@g.unibuc.ro; Tel.: +40-723-250-470
} Composition, Microbicidal,

Virulence-Arresting and

Antibiotic-Enhancing Activity of Essential Oils from Four Coniferous Species. Pharmaceuticals 2021, 14, 1159. https://doi.org/10.3390/ph14111159

Academic Editors: Víctor López and Filippo Maggi

Received: 11 October 2021

Accepted: 10 November 2021

Published: 13 November 2021

Publisher's Note: MDPI stays neutral with regard to jurisdictional claims in published maps and institutional affiliations.

Copyright: () 2021 by the authors. Licensee MDPI, Basel, Switzerland. This article is an open access article distributed under the terms and conditions of the Creative Commons Attribution (CC BY) license (https:// creativecommons.org/licenses/by/ $4.0 /)$.

\begin{abstract}
This study aimed to establish the essential oil (EO) composition from young shoots of Picea abies, Larix decidua, Pseudotsuga menziesii, and Pinus nigra harvested from Romania and evaluate their antimicrobial and anti-virulence activity, as well as potential synergies with currently used antibiotics. The samples' EO average content varied between $0.62 \%$ and $1.02 \%(\mathrm{~mL} / 100 \mathrm{~g}$ plant). The mono- and sesquiterpene hydrocarbons were dominant in the composition of the studied EOs. The antimicrobial activity revealed that the minimum inhibitory concentration (MIC) values for the tested EOs and some pure compounds known for their antimicrobial activity ranged from 6.25 to $100 \mu \mathrm{L} / \mathrm{mL}$. The most intensive antimicrobial effect was obtained for the Pinus nigra EO, which exhibited the best synergistic effect with some antibiotics against Staphylococcus aureus strains (i.e., oxacillin, tetracycline, erythromycin and gentamycin). The subinhibitory concentrations (sMIC) of the coniferous EOs inhibited the expression of soluble virulence factors (DN-ase, lipase, lecithinase, hemolysins, caseinase and siderophore-like), their efficiency being similar to that of the tested pure compounds, and inhibited the rhl gene expression in Pseudomonas aeruginosa, suggesting their virulence-arresting drug potential.
\end{abstract}

Keywords: essential oil; antimicrobial activity; Picea abies; Larix decidua; Pseudotsuga menziesii; Pinus nigra; quorum sensing

\section{Introduction}

Plant essential oils (EOs) are complex mixtures of volatile natural compounds. EOs are formed in aromatic plants as secondary metabolites (terpenes, terpenoids, phenylpropenes and "others") [1], which play an important role in plant defense [2] and have been used since ancient times as natural remedies for fighting infectious diseases caused by different microbial and viral pathogens [3-5]. They are relatively easy to obtain, have 
low mammalian toxicity, and degrade quickly in water and soil, making them relatively environmentally friendly [1].

It has been shown that plant extracts have pronounced antimicrobial activities, even when used in subinhibitory concentrations, which do not interfere with bacteria growth but only with their behavior [6], leading to a reduced risk of developing resistance to that compound and to a lower risk of dysbiosis [7]. Moreover, these low concentrations will have minimal or no effect against host cells. Taking into account these aspects, the most recent anti-infective approaches, also called anti-pathogenic or anti-virulence strategies, propose targeting virulence factors expression and biofilm development rather than inhibition of microbial growth or killing the pathogens $[6,8]$. Despite their superior resistance to antibiotics, biofilm-embedded bacteria seem to be more susceptible than their planktonic counterparts to some EOs, probably because (i) the extracellular matrix of the biofilm adsorbs the active phytocomponents and increases their local concentration; and (ii) the cellular envelope (capsule, cellular wall and membrane) in biofilm cells is different from that of free cells due to differential gene expression in the two growth states and more susceptible to EOs [9].

For this study we have chosen to evaluate the EOs of four coniferous species, being known that coniferous forests are a renewable source of EOs that are distributed in various organs of these plants: needle/leaves, roots, cones/seeds, wood/stem/twigs, bark and berries [8].

The EOs main compounds of coniferous species are monoterpenes, monoterpenoides, sesquiterpenes, sesquiterpenoides and diterpenes [10,11]; however, the chemical composition of EOs could be variable, depending on the anatomical part of the tree, the genetic factors [12], the health condition of plant and also on the geographic and environmental conditions: soil and water composition, humidity and air pollution [13-15]. Research conducted in recent decades have highlighted the antibacterial [16,17], antifungal [17-20] and antioxidant [21,22] properties of EOs isolated from different coniferous species $[15,19,22-30]$ but there is scarce information concerning the biologically active principles isolated from populations of coniferous species on the Romanian territory. This type of research is very important if we consider that Romania is the first place in Europe regarding the rates of antimicrobial resistance [11,31]. We have previously shown that the Abies alba EO inhibits agrI gene expression in Staphylococcus aureus, suggesting an inhibitory effect on the quorum sensing (QS) genes expression and indirectly on the strain virulence, and therefore their anti-pathogenic potential [32].

The objectives of this study were to investigate the composition of the EOs from young shoots of four coniferous species and to evaluate their antimicrobial activity. The biological material consisted of three Eurasian species native to the Carpathian area-spruce (Picea abies), larch (Larix decidua) and black pine (Pinus nigra) —and a species of North American origin - the Douglas fir (Pseudotsuga menziesii) —naturalized and often used in forest plantations in Europe.

\section{Results and Discussion}

\subsection{Essential Oil Content and Composition}

The average EO content of the P. abies, L. decidua, P. menziesii and P. nigra samples (five determinations for each sample) was $1.02 \pm 0.19,0.62 \pm 0.13,0.87 \pm 0.04$ and $0.82 \pm 0.14 \%$ (mL essential oil/100 g dried plant), respectively. Figure 1 shows the chromatogram of the P. abies EO and in Table 1 are listed the identified compounds for all four EO samples. The other chromatograms of the EOs are included in Supplementary Materials (Figures S1-S3). The numbers from the peak of the compounds on the four chromatograms correspond to the numbers listed in Table 1. 


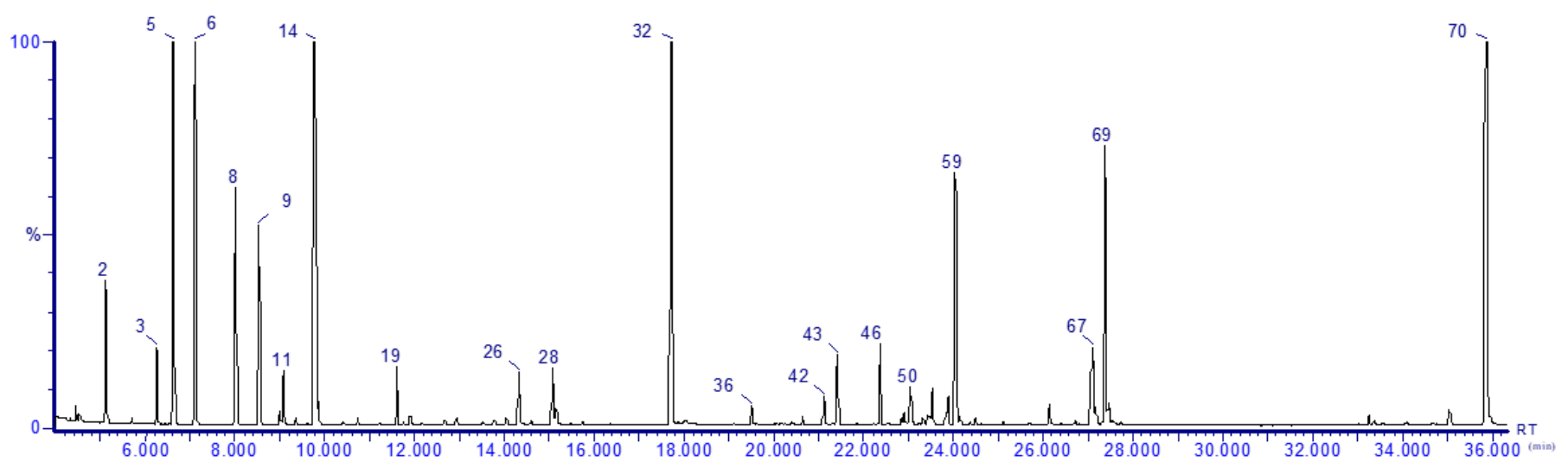

Figure 1. Chromatogram of the P. abies essential oil.

Table 1. The chemical composition of P. abies, L. decidua, P. menziesii and P. nigra EOs obtained by gas chromatography coupled with mass spectrometry.

\begin{tabular}{|c|c|c|c|c|c|c|c|}
\hline \multirow{2}{*}{ No. } & \multirow{2}{*}{ Compound Name } & \multirow{2}{*}{$\begin{array}{c}\text { RI } \\
\text { Exp }\end{array}$} & \multirow{2}{*}{$\begin{array}{c}\mathrm{RI}^{\mathrm{a}} \\
\text { Lit }\end{array}$} & \multicolumn{4}{|c|}{ Relative Area (\%) } \\
\hline & & & & $\mathbf{P a}^{\mathbf{b}}$ & $\operatorname{Ld}^{b}$ & $\operatorname{Pm}^{b}$ & $\operatorname{Pn}^{b}$ \\
\hline 1 & 4-hexen-1-ol & 872 & 879 & $\mathrm{Tr}$ & $0.42 \pm 0.03$ & $0.10 \pm 0.01$ & \\
\hline 2 & santene & 887 & 888 & $3.83 \pm 1.10$ & & & \\
\hline 3 & tricyclene & 921 & 926 & $1.23 \pm 0.23$ & $0.10 \pm 0.01$ & $0.09 \pm 0.03$ & $0.11 \pm 0.01$ \\
\hline 4 & $\alpha$-thujene & 928 & 931 & & $\operatorname{Tr}$ & $0.27 \pm 0.01$ & $0.08 \pm 0.04$ \\
\hline 5 & $\alpha$-pinene & 934 & 939 & $11.64 \pm 1.34$ & $26.99 \pm 2.57$ & $18.42 \pm 2.29$ & $74.27 \pm 2.73$ \\
\hline 6 & camphene & 950 & 952 & $10.70 \pm 0.25$ & $0.52 \pm 0.15$ & $0.62 \pm 0.10$ & $1.24 \pm 0.12$ \\
\hline 7 & sabinene & 973 & 973 & & $0.15 \pm 0.07$ & $1.67 \pm 0.59$ & $0.02 \pm 0.01$ \\
\hline 8 & $\beta$-pinene & 976 & 980 & $4.62 \pm 1.34$ & $8.20 \pm 0.83$ & $49.84 \pm 3.57$ & $4.33 \pm 0.55$ \\
\hline 9 & $\beta$-myrcene & 991 & 991 & $2.26 \pm 0.49$ & $2.05 \pm 0.52$ & $1.17 \pm 0.12$ & $0.70 \pm 0.18$ \\
\hline 10 & $\alpha$-phellandrene & 1003 & 1005 & $0.13 \pm 0.07$ & $0.32 \pm 0.18$ & $0.15 \pm 0.01$ & $0.05 \pm 0.01$ \\
\hline 11 & $\delta$-3-carene & 1006 & 1009 & $0.89 \pm 0.21$ & $5.97 \pm 1.19$ & $0.66 \pm 0.10$ & $\operatorname{Tr}$ \\
\hline 12 & $\alpha$-terpinene & 1016 & 1017 & $0.08 \pm 0.03$ & $0.38 \pm 0.10$ & $0.87 \pm 0.19$ & $0.05 \pm 0.01$ \\
\hline 13 & p-cymene & 1024 & 1026 & $0.05 \pm 0.01$ & $0.06 \pm 0.01$ & $0.36 \pm 0.14$ & $0.04 \pm 0.01$ \\
\hline 14 & limonene & 1029 & 1031 & $21.14 \pm 2.27$ & $6.69 \pm 0.93$ & $3.58 \pm 0.26$ & $7.06 \pm 0.78$ \\
\hline 15 & 1,8-cineole & 1032 & 1033 & $0.18 \pm 0.11$ & $0.22 \pm 0.01$ & & \\
\hline 16 & (Z)- $\beta$-ocimene & 1040 & 1040 & $\operatorname{Tr}$ & & $\operatorname{Tr}$ & $\operatorname{Tr}$ \\
\hline 17 & (E)- $\beta$-ocimene & 1050 & 1050 & $0.05 \pm 0.01$ & & & $0.50 \pm 0.21$ \\
\hline 18 & $\gamma$-terpinene & 1060 & 1062 & $0.07 \pm 0.02$ & $0.48 \pm 0.23$ & $1.38 \pm 0.31$ & $0.08 \pm 0.06$ \\
\hline 19 & $\alpha$-terpinolene & 1085 & 1084 & $0.64 \pm 0.23$ & $1.59 \pm 0.54$ & $3.71 \pm 1.02$ & $0.22 \pm 0.07$ \\
\hline 20 & linalool & 1100 & 1100 & $\operatorname{Tr}$ & $0.07 \pm 0.04$ & & $0.04 \pm 0.03$ \\
\hline 21 & fenchol & 1117 & 1117 & $0.07 \pm 0.01$ & $0.14 \pm 0.10$ & & \\
\hline 22 & $\alpha$-campholenal & 1126 & 1027 & $0.11 \pm 0.03$ & & & $0.10 \pm 0.00$ \\
\hline 23 & camphor & 1145 & 1145 & $0.06 \pm 0.03$ & & & \\
\hline 24 & ethyl benzoate & 1169 & 1170 & & $0.49 \pm 0.01$ & & \\
\hline 25 & $\beta$-terpineol & 1154 & 1159 & $0.07 \pm 0.02$ & & & \\
\hline 26 & borneol & 1171 & 1171 & $0.78 \pm 0.06$ & & $0.09 \pm 0.01$ & $0.12 \pm 0.06$ \\
\hline 27 & terpinen-4-ol & 1180 & 1179 & $0.08 \pm 0.00$ & $0.60 \pm 0.33$ & $2.24 \pm 0.18$ & $0.04 \pm 0.01$ \\
\hline 28 & $\alpha$-terpineol & 1193 & 1197 & $0.57 \pm 0.04$ & $2.27 \pm 0.62$ & $1.86 \pm 0.44$ & $0.35 \pm 0.14$ \\
\hline 29 & estragole & 1196 & 1195 & $0.27 \pm 0.01$ & & & \\
\hline 30 & fenchyl acetate & 1216 & 1220 & $0.05 \pm 0.01$ & & & \\
\hline 31 & methyl thymyl ether & 1231 & 1235 & & $\operatorname{Tr}$ & $\operatorname{Tr}$ & $0.04 \pm 0.01$ \\
\hline 32 & bornyl acetate & 1283 & 1285 & $11.08 \pm 1.80$ & $1.26 \pm 0.04$ & $0.20 \pm 0.04$ & $1.21 \pm 0.17$ \\
\hline 33 & sabinyl acetate & 1293 & 1293 & $0.16 \pm 0.01$ & & & \\
\hline 34 & $\delta$-elemene & 1334 & 1337 & & & $0.6 \pm 0.43$ & \\
\hline 35 & terpenyl acetate & 1347 & 1351 & & $0.18 \pm 0.01$ & & \\
\hline 36 & $\alpha$-longipinene & 1349 & 1351 & $0.34 \pm 0.03$ & & & \\
\hline
\end{tabular}


Table 1. Cont

\begin{tabular}{|c|c|c|c|c|c|c|c|}
\hline \multirow{2}{*}{ No. } & \multirow{2}{*}{ Compound Name } & \multirow{2}{*}{$\begin{array}{c}\text { RI } \\
\text { Exp }\end{array}$} & \multirow{2}{*}{$\begin{array}{c}\mathrm{RI}^{\mathrm{a}} \\
\mathrm{Lit}^{-}\end{array}$} & \multicolumn{4}{|c|}{ Relative Area (\%) } \\
\hline & & & & $\mathrm{Pa}^{\mathrm{b}}$ & $\operatorname{Ld}^{b}$ & $\operatorname{Pm}^{\mathrm{b}}$ & $\mathrm{Pn}^{\mathrm{b}}$ \\
\hline 37 & citronellyl acetate & 1351 & 1354 & $0.04 \pm 0.01$ & $0.06 \pm 0.01$ & $\operatorname{Tr}$ & \\
\hline 38 & longicyclene & 1371 & 1373 & $0.05 \pm 0.03$ & & & \\
\hline 39 & $\alpha$-copaene & 1375 & 1376 & $0.06 \pm 0.03$ & $0.08 \pm 0.03$ & & $0.03 \pm 0.03$ \\
\hline 40 & geranyl acetate & 1380 & 1382 & $0.04 \pm 0.03$ & & & $0.12 \pm 0.01$ \\
\hline 41 & $\beta$-elemene & 1387 & 1391 & $0.15 \pm 0.03$ & $0.27 \pm 0.03$ & $0.42 \pm 0.26$ & \\
\hline 42 & longifolene & 1404 & 1408 & $0.50 \pm 0.09$ & & & \\
\hline 43 & trans-caryophyllene & 1416 & 1415 & $1.17 \pm 0.13$ & $2.68 \pm 0.18$ & $0.34 \pm 0.16$ & $1.99 \pm 0.30$ \\
\hline 44 & $\gamma$-elemene & 1428 & 1430 & & & $0.13 \pm 0.01$ & \\
\hline 45 & $\begin{array}{c}\text { trans- } \alpha- \\
\text { bergamotene }\end{array}$ & 1432 & 1436 & $0.04 \pm 0.01$ & & $0.48 \pm 0.04$ & \\
\hline 46 & $\alpha$-humulene & 1453 & 1452 & $1.23 \pm 0.04$ & $1.12 \pm 0.13$ & $1.07 \pm 0.54$ & $0.27 \pm 0.03$ \\
\hline 47 & ethyl cinnamate & 1464 & 1460 & & $0.11 \pm 0.01$ & & \\
\hline 48 & $\beta$-cadinene & 1470 & 1472 & $0.15 \pm 0.06$ & $0.16 \pm 0.07$ & & \\
\hline 49 & $\gamma$-muurolene & 1473 & 1477 & $0.24 \pm 0.03$ & $0.76 \pm 0.06$ & $0.20 \pm 0.04$ & $0.16 \pm 0.04$ \\
\hline 50 & germacrene D & 1478 & 1480 & $0.76 \pm 0.07$ & $19.80 \pm 4.40$ & $5.47 \pm 2.70$ & $2.74 \pm 1.07$ \\
\hline 51 & ledene & 1485 & 1487 & & $0.08 \pm 0.01$ & & \\
\hline 52 & $\begin{array}{l}\text { phenylethyl } \\
\text { isovalerate }\end{array}$ & 1489 & 1489 & & & & $0.03 \pm 0.01$ \\
\hline 53 & valencene & 1491 & 1490 & $0.10 \pm 0.01$ & & & $0.06 \pm 0.04$ \\
\hline 54 & $\beta$-selinene & 1485 & 1485 & $0.05 \pm 0.04$ & & $0.38 \pm 0.18$ & \\
\hline 55 & $\alpha$-selinene & 1493 & 1494 & $0.19 \pm 0.08$ & & & \\
\hline 56 & $\alpha$-muurolene & 1496 & 1499 & $0.75 \pm 0.13$ & $1.01 \pm 0.18$ & $0.09 \pm 0.01$ & $0.13 \pm 0.06$ \\
\hline 57 & $\alpha$-farnesene & 1504 & 1508 & $0.25 \pm 0.01$ & & & \\
\hline 58 & $\gamma$-cadinene & 1510 & 1514 & $0.86 \pm 0.31$ & $0.72 \pm 0.04$ & $0.20 \pm 0.01$ & $0.11 \pm 0.03$ \\
\hline 59 & $\delta$-cadinene & 1517 & 1523 & $4.21 \pm 0.69$ & $4.52 \pm 0.66$ & $0.74 \pm 0.01$ & $0.34 \pm 0.06$ \\
\hline 60 & zonarene & 1521 & 1526 & $0.15 \pm 0.07$ & $0.16 \pm 0.06$ & & \\
\hline 61 & cadina-1,4-diene & 1531 & 1532 & $0.07 \pm 0.04$ & $0.10 \pm 0.00$ & & \\
\hline 62 & $\alpha$-cadinene & 1536 & 1538 & $0.14 \pm 0.07$ & $0.17 \pm 0.04$ & & \\
\hline 63 & trans- $\alpha$-bisabolene & 1541 & 1544 & & & $0.95 \pm 0.24$ & \\
\hline 64 & germacrene B & 1553 & 1560 & & $0.10 \pm 0.04$ & $0.30 \pm 0.00$ & \\
\hline 65 & nerolidol & 1560 & 1565 & $0.06 \pm 0.00$ & $0.04 \pm 0.01$ & & \\
\hline 66 & $\gamma$-eudesmol & 1631 & 1630 & & & $0.11 \pm 0.01$ & \\
\hline 67 & $\alpha$-muurolol & 1643 & 1645 & $2.15 \pm 0.28$ & $2.55 \pm 0.54$ & & \\
\hline 68 & $\delta$-cadinol & 1646 & 1646 & $0.32 \pm 0.05$ & & & \\
\hline 69 & $\alpha$-cadinol & 1655 & 1656 & $3.78 \pm 0.76$ & $4.11 \pm 0.88$ & $0.36 \pm 0.21$ & \\
\hline 70 & manool & 2053 & 2056 & $9.40 \pm 1.85$ & & & \\
\hline 71 & verticillol & 2102 & $2106^{c}$ & & & & $2.14 \pm 1.60$ \\
\hline \multicolumn{4}{|c|}{ TOTAL } & $98.06 \pm 0.97$ & $97.75 \pm 2.23$ & $99.13 \pm 0.04$ & $98.77 \pm 1.68$ \\
\hline \multicolumn{4}{|c|}{ Monoterpene hydrocarbons } & $57.77 \pm 3.85$ & $52.90 \pm 0.53$ & $82.50 \pm 6.68$ & $88.56 \pm 4.83$ \\
\hline \multicolumn{4}{|c|}{ Sesquiterpene hydrocarbons } & $11.43 \pm 1.78$ & $31.63 \pm 6.53$ & $11.22 \pm 4.35$ & $5.83 \pm 2.09$ \\
\hline \multicolumn{4}{|c|}{ Monoterpene alcohols and esters } & $12.90 \pm 2.97$ & $4.01 \pm 1.85$ & $4.39 \pm 0.31$ & $1.86 \pm 0.32$ \\
\hline \multicolumn{4}{|c|}{ Sesquiterpene alcohols } & $6.28 \pm 0.48$ & $6.69 \pm 1.43$ & $0.39 \pm 0.31$ & 0.00 \\
\hline \multicolumn{4}{|c|}{ Diterpene alcohols } & $9.40 \pm 1.85$ & 0 & 0 & $2.14 \pm 1.60$ \\
\hline
\end{tabular}

${ }^{\mathrm{a}} \mathrm{RI}$, the retention index relative to $\mathrm{C}_{8}-\mathrm{C}_{24}$ n-alkanes on a DB-5MS column. ${ }^{\mathrm{b}}$ Pa: P. abies; Ld: L. decidua; Pm: P. menziesii; Pn: P. nigra. ${ }^{\mathrm{c}}$ [33].

The main compound classes from the studied EOs were mono- and sesquiterpene hydrocarbons, representing $69.20 \%$ (P. abies), 84.53\% (L. decidua), 93.72\% (P. menziesii) and 94.39\% (P. nigra) from each EO.

Camphene, $\alpha$-pinene, $\beta$-pinene and limonene are prevalent among the monoterpene hydrocarbons. The EO compositions isolated from P. abies [11], L. decidua and P. menziesii [34] are similar to the previously published papers. For the EO extracted from P. abies, the content in compounds with oxygen is significantly higher than in other oils, i.e., $11.08 \%$ for bornyl acetate, $9.40 \%$ for manool, 3.87\% for $\alpha$-cadinol, and $2.15 \%$ for $\alpha$-muurolol. Germacrene $\mathrm{D}$ is the major compound $(19.80 \%$ ) in the EO of Larix decidua, while pinene ( $\alpha$ and 
$\beta$ ) is one of the most important components of the EO extracted from P. abies, these data being in accordance with those reported by Mofikoya (2020) [35].

\subsection{Antimicrobial Activity}

\subsubsection{Qualitative and Quantitative Analysis}

The qualitative screening of the EOs and the pure compounds revealed the occurrence of a growth inhibition zone in the area where the EOs: DMSO stock solution was spotted. We started by assessing the efficiency of the tested EOs against a larger batch of microbial strains, but only those strains for which a growth inhibition zone was observed were further tested by quantitative assay. Thus, in Table 2 are presented only the strains that proved to be sensitive to the EOs and pure compounds when tested by the qualitative assay.

Table 2. The MIC $(\mu \mathrm{L} / \mathrm{mL})$ a and $\operatorname{MBEC}(\mu \mathrm{L} / \mathrm{mL})$ b values for P. abies, L. decidua, P. menziesii and P. nigra essential oils and for some pure compounds against Gram-positive bacteria, Gram-negative bacteria and C. albicans.

\begin{tabular}{|c|c|c|c|c|c|c|c|c|c|c|c|c|c|}
\hline Strain & $\begin{array}{l}\mathbf{a} \\
\mathbf{b}\end{array}$ & Pin & Lim & Phel & Bor & Cam & Cin & Ner & $\mathrm{Pa}$ & $L d$ & $P m$ & $P n$ & Gen \\
\hline \multirow{2}{*}{ S. aureus ATCC 25923} & a & 50 & 25 & 50 & 50 & 50 & 25 & 50 & 25 & 12.5 & 6.25 & 12.5 & 0.48 \\
\hline & $\mathrm{b}$ & 25 & 12.5 & 25 & 25 & 25 & 12.5 & 25 & 12.5 & 6.25 & 3.13 & 6.25 & n.t. \\
\hline \multirow{2}{*}{$\begin{array}{l}\text { S. aureus } \\
19 \mathrm{~F}\end{array}$} & a & 50 & 50 & 50 & 50 & 50 & 50 & 50 & 6.25 & 50 & 25 & 25 & 0.48 \\
\hline & $\mathrm{b}$ & 25 & 25 & 25 & 25 & 25 & 25 & 25 & 3.13 & 25 & 12.5 & 12.5 & n.t. \\
\hline \multirow{2}{*}{ S. aureus $8 \mathrm{~V}$} & a & 25 & 50 & 50 & 50 & 50 & 50 & 50 & 20 & 25 & 25 & 25 & 0.96 \\
\hline & $\mathrm{b}$ & 12.5 & 25 & 25 & 25 & 25 & 25 & 25 & 10 & 12.5 & 12.5 & 12.5 & n.t. \\
\hline \multirow{2}{*}{ S. aureus $12 \mathrm{H}$} & a & 12.5 & 50 & 50 & 50 & 50 & 50 & 50 & 6.25 & 50 & 25 & 6.25 & 0.96 \\
\hline & $\mathrm{b}$ & 6.25 & 25 & 25 & 25 & 25 & 25 & 25 & 3.13 & 25 & 12.5 & 3.13 & n.t. \\
\hline \multirow{2}{*}{ S. aureus $35 \mathrm{PL}$} & a & 12.5 & 50 & 50 & 50 & 50 & 50 & 50 & 6.25 & 25 & 25 & 6.25 & 2.88 \\
\hline & $\mathrm{b}$ & 6.25 & 25 & 25 & 25 & 25 & 25 & 25 & 3.13 & 12.5 & 12.5 & 3.13 & n.t. \\
\hline \multirow{2}{*}{$\begin{array}{c}\text { Pseudomonas aeruginosa } \\
\text { ATCC } 27853\end{array}$} & a & 25 & 50 & 50 & 50 & 50 & 50 & 50 & 50 & 50 & 25 & 25 & 1.96 \\
\hline & $\mathrm{b}$ & 12.5 & 25 & 25 & 25 & 25 & 25 & 25 & 25 & 25 & 2512.5 & 12.5 & n.t. \\
\hline \multirow{2}{*}{ P. aeruginosa $1 \mathrm{H}$} & a & 25 & 25 & 50 & 50 & 50 & 50 & 50 & 50 & 50 & 25 & 25 & 7.84 \\
\hline & $\mathrm{b}$ & 12.5 & 12.5 & 25 & 25 & 25 & 25 & 25 & 25 & 25 & 12.5 & 12.5 & n.t. \\
\hline \multirow{2}{*}{ P. aeruginosa $61 / 2$} & a & 50 & 50 & 50 & 50 & 50 & 50 & 50 & 50 & 50 & 25 & 25 & 15.68 \\
\hline & $\mathrm{b}$ & 25 & 25 & 25 & 25 & 25 & 25 & 25 & 25 & 25 & 12.5 & 12.5 & n.t. \\
\hline \multirow{2}{*}{ P. aeruginosa 399} & a & 50 & 50 & 25 & 25 & 25 & 25 & 25 & 50 & 50 & 50 & 25 & 15.68 \\
\hline & $\mathrm{b}$ & 25 & 25 & 12.5 & 12.5 & 12.5 & 12.5 & 12.5 & 25 & 25 & 25 & 12.5 & n.t. \\
\hline \multirow{2}{*}{ P. aeruginosa $261 / 1$} & $\mathrm{a}$ & 50 & 50 & 25 & 25 & 25 & 25 & 25 & 50 & 50 & 50 & 25 & 7.84 \\
\hline & $\mathrm{b}$ & 25 & 25 & 12.5 & 12.5 & 12.5 & 12.5 & 12.5 & 25 & 25 & 25 & 12.5 & n.t. \\
\hline \multirow{2}{*}{ B. subtilis 6633} & a & n.t. & n.t. & n.t. & n.t. & n.t. & n.t. & n.t. & 6.25 & 50 & 25 & 6.25 & 0.24 \\
\hline & $\mathrm{b}$ & n.t. & n.t. & n.t. & n.t. & n.t. & n.t. & n.t. & 3.13 & 25 & 12.5 & 3.13 & n.t. \\
\hline \multirow{2}{*}{ E. faecalis ATCC 29212} & a & n.t. & n.t. & n.t. & n.t. & n.t. & n.t. & n.t. & 25 & 50 & 50 & 25 & 7.68 \\
\hline & $\mathrm{b}$ & n.t. & n.t. & n.t. & n.t. & n.t. & n.t. & n.t. & 12.5 & 25 & 25 & 12.5 & n.t. \\
\hline \multirow{2}{*}{ E. coli ATCC 25922} & $\mathrm{a}$ & n.t. & n.t. & n.t. & n.t. & n.t. & n.t. & n.t. & 50 & 50 & 50 & 25 & 0.48 \\
\hline & $\mathrm{b}$ & n.t. & n.t. & n.t. & n.t. & n.t. & n.t. & n.t. & 25 & 25 & 25 & 12.5 & n.t. \\
\hline \multirow{2}{*}{ C. albicans ATCC 10231} & $\mathrm{a}$ & n.t. & n.t. & n.t. & n.t. & n.t. & n.t. & n.t. & 6.25 & 25 & 25 & 6.25 & n.t. \\
\hline & $\mathrm{b}$ & n.t. & n.t. & n.t. & n.t. & n.t. & n.t. & n.t. & 3.13 & 12.5 & 12.5 & 3.13 & n.t. \\
\hline
\end{tabular}

a: MIC $(\mu \mathrm{L} / \mathrm{mL})$ : minimum inhibitory concentration; b: MBEC $(\mu \mathrm{L} / \mathrm{mL})$ : minimum biofilm eradication concentration on an inert substrate; Pin: $\alpha$-pinene; Lim: (+)-limonene; Phel: phellandrene; Bor: borneol; Cam: camphor; Cin: 1,8-cineole; Ner: nerolidol; Pa: P. abies; Ld: L. decidua; Pm: P. menziesii; Pn: P. nigra, Gen: gentamycin $(\mu \mathrm{g} / \mathrm{mL})$, n.t. $=$ not tested. 
The quantitative assay revealed that the MIC values for the tested EOs as well as for some pure compounds known for their antimicrobial activity ranged from 6.25 to $50 \mu \mathrm{L} / \mathrm{mL}$, the most intensive effect being obtained for P. nigra, exhibiting the lowest MIC values against all tested strains (Table 2).

Concerning the antimicrobial activity of the pure compounds, the most active proved to be $\alpha$-pinene, $S$. aureus strains being more susceptible than the Gram-negative ones. Phellandrene, borneol and camphor had the same effect as nerolidol. The EOs proved also to be more effective against S. aureus strains, as well as towards Bacillus subtilis and Candida albicans strains, as compared to the Gram-negative species. It is to be noticed that in many cases, the MIC values were lower for the EOs than those obtained for the pure compounds, demonstrating the synergistic effect of the active compounds found in the EOs. The antimicrobial activity of $P$. abies EO could mainly be due to bornyl acetate because this compound has shown a good activity on S. aureus (MIC $1.95 \mathrm{mg} / \mathrm{mL}$ ), P aeruginosa (MIC $2.30 \mathrm{mg} / \mathrm{mL}$ ) and Escherichia coli (MIC $4.88 \mathrm{mg} / \mathrm{mL}$ ) [36]. Some studies showed that $\alpha$-pinene and $\beta$-pinene are able to destroy the cellular integrity by inhibition of respiration and ion transport processes [37,38]. Helander et al. [39] showed that the low molecular mass lipophilic compounds are responsible for the toxicity of EO components on Gramnegative bacteria because these compounds are able to penetrate the bacterial membrane and may thus be able to influence the proliferation of certain pathogenic bacteria.

By comparing the effect of the P. abies EO on Gram-positive and Gram-negative strains, a statistically significant activity was observed for Gram-positive bacteria $(p<0.001)$ (Figure 2a). For L. decidua, P. menziesii and P. nigra, the difference between the antimicrobial activity on Gram-positive and Gram-negative strains was not significant $(p>0.05)$, despite the fact that a better effect was observed on Gram-positive bacteria (Figure $2 b-d$ ).

According to Magwa et al. [40], Sesuvium portulacastrum exhibited an antibacterial activity against $S$. aureus, which may be due to the camphene found in its EO. This compound, identified in the analyzed conifer EOs, seems to be responsible for their antibacterial activity, especially on Gram-positive bacteria, because P. abies has the highest concentration of camphene and the best effect on S. aureus and B. subtilis. The presence of trans-caryophyllene and camphene, known to possess antifungal activity [40,41], in the studied EO composition explain the effect on the Candida strain. The P. abies EO had the biggest percent of these compounds (camphene: $10.7 \%$ and trans-caryophyllene: $1.17 \%$ ) and the best antifungal activity, followed by P. nigra (with camphene: $1.24 \%$ and trans-caryophyllene: $1.99 \%$ ).

\subsubsection{The Adherence Capacity to the Inert Substrate}

In the natural environment, but also in the infected host, microorganisms usually produce extracellular capsular polymers, mostly polysaccharides, known as a capsule, slime, or glycocalyx, which, in the case of pathogenic strains, are an important virulence factor, being involved in adhesion and colonization of inert substrata, such as medical devices [42].

The adherence capacity to the inert substrate of the reference and clinical strains was inhibited by all the tested EOs and pure compounds at subinhibitory concentrations, respectively, MIC $/ 2$. The results are represented as the minimum biofilm eradication concentration (MBEC) values in Table 2. These results show the promising potential of these EOs to appropriately address the challenges of biofilm-associated infections diagnosis and treatment, often remaining unresolved with the present approaches [43,44]. 
Estimation Plot
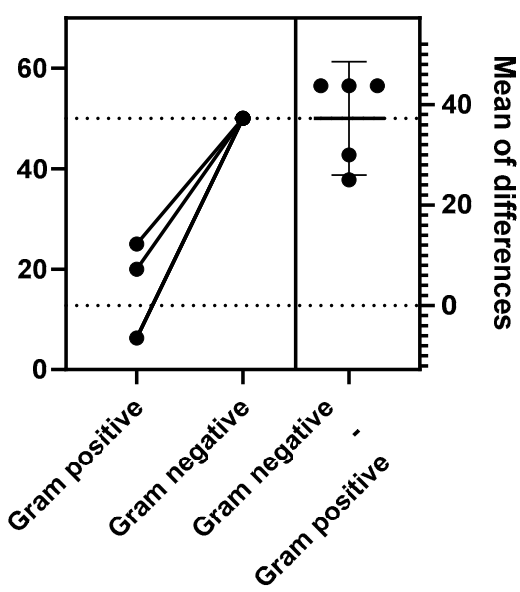

(a)

Estimation Plot
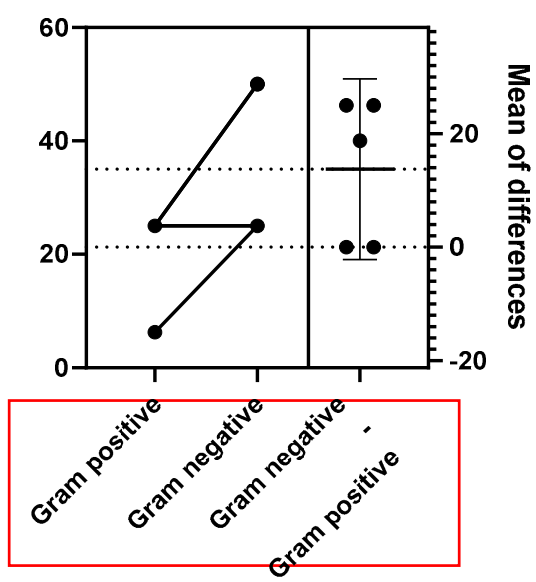

(c)

\section{Estimation Plot}

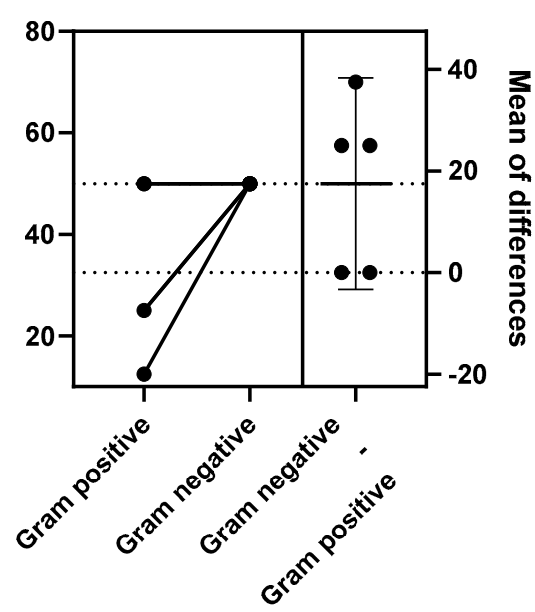

(b)

\section{Estimation Plot}

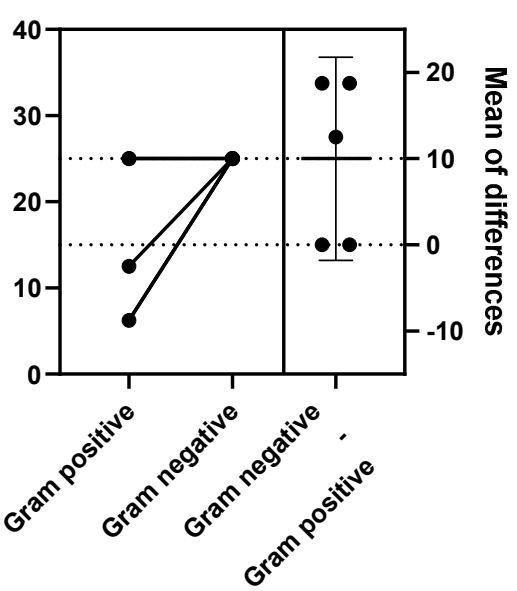

(d)

Figure 2. Estimation plots of the antibacterial activity of the P. abies (a), L. decidua (b), P. menziesii (c) and P. nigra (d) EOs. The Gram-negative-Gram-positive effect size is generated by the difference between means. The precision of the calculated effect size was at a 95\% confidence interval.

\subsubsection{The Synergistic Activity with Antibiotics}

The tested EOs potentiated the currently used antibiotics against $S$. aureus and $P$. aeruginosa strains, the most intensive effect being observed in case of $P$. nigra. The $S$. aureus $12 \mathrm{H}$ strain, in the presence of EOs obtained from P. abies and P. menziesii, switched from resistant to susceptible to oxacillin and tetracycline, and in the presence of the P. nigra $\mathrm{EO}$, to erythromycin, while $S$. aureus $35 \mathrm{PL}$ became susceptible to gentamycin (Table 3). In case of the P. aeruginosa strains, the growth inhibition diameters for piperacillin, ticarcillinclavulanic acid, imipenem, aztreonam, ceftazidime, ciprofloxacin, colistin and gentamycin were not modified by the EOs, probably due to the multi-drug resistance phenotype of these strains, which is often mediated by efflux pumps that are not substrate-specific, thus being able to provide cross-resistance to the EOs [45]. 
Table 3. The synergistic activity of the tested EOs with different antibiotics.

\begin{tabular}{|c|c|c|c|c|c|c|c|c|}
\hline \multirow{2}{*}{ Strains } & \multirow{2}{*}{ Sample } & \multicolumn{7}{|c|}{ The Diameter of the Inhibition Zones (mm) } \\
\hline & & oxa & cli & cip & tet & gen & pen & ery \\
\hline \multirow{5}{*}{$\begin{array}{c}\text { S. aureus } \\
\text { ATCC } 25923\end{array}$} & control & 18 & 32 & 22 & 24 & 22 & 26 & 26 \\
\hline & P. abies & 18 & 40 & 26 & 23 & 23 & 26 & 30 \\
\hline & L. decidua & 18 & 30 & 24 & 22 & 22 & 26 & 22 \\
\hline & P.menziesii & 18 & 26 & 24 & 23 & 21 & 26 & 26 \\
\hline & P. nigra & 18 & 38 & 27 & 22 & 24 & 26 & 23 \\
\hline \multirow{5}{*}{ S. aureus $19 \mathrm{~F}$} & control & 10 & 32 & 28 & 22 & 19 & 0 & 22 \\
\hline & P. abies & 10 & 28 & 33 & 21 & 21 & 8 & 22 \\
\hline & L. decidua & 10 & 40 & 32 & 20 & 25 & 13 & 27 \\
\hline & P.menziesii & 10 & 36 & 28 & 22 & 23 & 18 & 25 \\
\hline & P. nigra & 10 & 34 & 29 & 22 & 23 & 7 & 27 \\
\hline \multirow{5}{*}{ S. aureus $8 \mathrm{~V}$} & control & 11 & 38 & 25 & 20 & 19 & 0 & 10 \\
\hline & P. abies & 11 & 34 & 27 & 21 & 21 & 0 & 9 \\
\hline & L. decidua & 11 & 33 & 27 & 21 & 21 & 0 & 11 \\
\hline & P.menziesii & 11 & 32 & 27 & 21 & 21 & 0 & 11 \\
\hline & P. nigra & 11 & 36 & 27 & 21 & 21 & 0 & 12 \\
\hline \multirow{5}{*}{ S. aureus $12 \mathrm{H}$} & control & 10 & 34 & 24 & 20 & 20 & 15 & 11 \\
\hline & P. abies & 10 & 36 & 27 & 26 & 21 & 19 & 12 \\
\hline & L. decidua & 10 & 38 & 28 & 22 & 19 & 15 & 12 \\
\hline & P.menziesii & 10 & 36 & 25 & 20 & 19 & 15 & 11 \\
\hline & P. nigra & 10 & 44 & 30 & 30 & 23 & 24 & 24 \\
\hline \multirow{5}{*}{$\begin{array}{c}\text { S. aureus } 35 \\
\text { PL }\end{array}$} & control & 14 & 25 & 23 & 0 & 18 & 0 & 0 \\
\hline & P. abies & 14 & 26 & 25 & 0 & 18 & 0 & 0 \\
\hline & L. decidua & 14 & 26 & 23 & 0 & 20 & 0 & 0 \\
\hline & P.menziesii & 14 & 28 & 24 & 0 & 19 & 8 & 0 \\
\hline & P. nigra & 14 & 29 & 24 & 9 & 20 & 0 & 0 \\
\hline
\end{tabular}

oxa = oxacillin; cli = clindamycin; cip = ciprofloxacin; tet = tetracycline; gen = gentamycin; pen = penicillin; ery $=$ erythromycin.

The synergic effects could be produced by $\alpha$-pinene, according to Kovač, who reported that the MICs reduced from 32 to over 512 -fold when (-)- $\alpha$-pinene was applied in combination with erythromycin, ciprofloxacin or triclosan [46].

Other recent studies revealed that numerous plant-derived compounds and EOs, by interfering with adherence, biofilm formation and motility, are also affecting antibiotic susceptibility [47-49].

\subsubsection{The Influence of EOs on the QS Genes Expression}

Taking into account the involvement of P. aeruginosa strains in the etiology of opportunistic and nosocomial infections, as well as their high resistance rates to the current antibiotics, a significant number of the respective strains isolated from clinical specimens have been tested in order to establish the modulatory effect of the EOs on the expression of QS genes. A relatively new strategy for combating bacterial infections and resistance to antibiotics is represented by QS inhibitors (QSI). Some EOs [50-53] or their components $[32,54,55]$ were already reported to inhibit QS genes expression. P. aeruginosa, a critical opportunistic nosocomial pathogen, produces different virulence factors synthesized under the control of QS systems las and rhl. The first one consists of LasI, which modulates the synthesis of the autoinducer $\mathrm{N}$-(3-oxododecanoyl) homoserine lactone, and a transcriptional activator (lasR). The second is composed of a putative transcriptional activator, rhlR and rhlI, which manage the synthesis of N-butyryl homoserine lactone. An interconnecting role between these two systems in the QS hierarchy of P. aeruginosa is held by the PQS signaling system (which produces 2-heptyl-3-hydroxy-4-quinolone) [56].

The rhl and lasR genes expression was significantly downregulated by the coniferous EOs, while lasI expression was upregulated (Figure 3). 


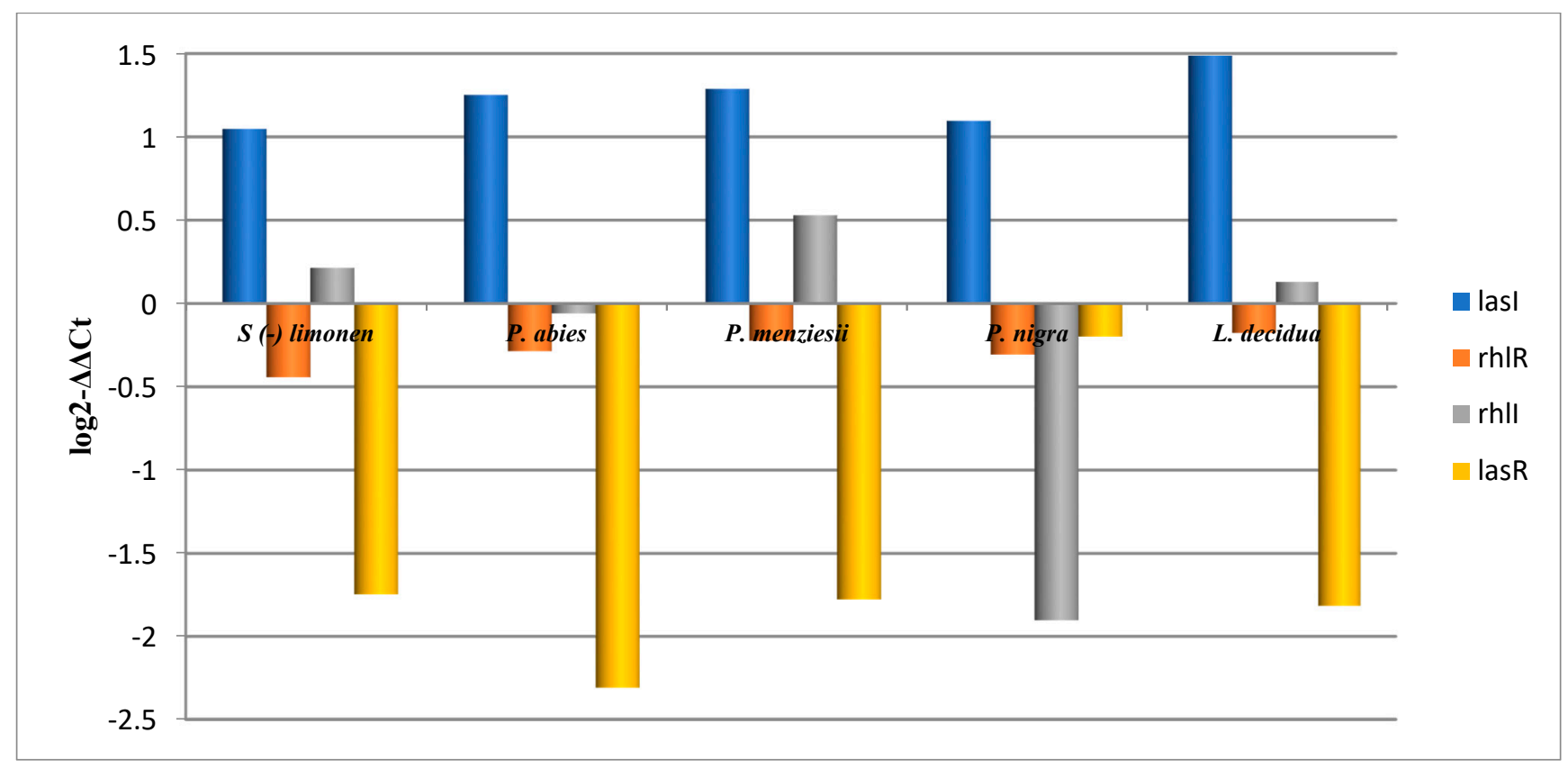

Figure 3. The QS genes expression levels in P. aeruginosa strains cultivated in the presence of limonene and EOs.

According to Kostylev (2019), the RhlIR QS system requires induction by LasR, and as a consequence, a decreasing in the expression of QS-activated genes could be possible by lasR or lasI deletion in strain PAO1 (a laboratory model P. aeruginosa strain) [57].

As a result, these findings suggest that EOs interfere with the QS pathways in P. aeruginos $a$ and could be a promising lead for the development of virulence-arresting drugs. These findings indicate that EOs may have an inhibitory effect on rhamnolipid production, which is regulated by the P. aeruginosa QS regulator $r h l R$, while an inhibitory effect on elastase and protease activities are regulated by the rhlI-rhlR system [58].

\subsection{Influence of EO on the Expression of Soluble Enzymatic Virulence Factors}

The tested strains have been previously analyzed for their virulence potential and selected as positive for producing the investigated virulence determinants, i.e., toxins forming pores in the membrane of eukaryotic cells (lecithinase, hemolysins and lipase), proteases (caseinase) and DN-ase [32].

Taking into account the rapid emergence of resistance to classical antimicrobial drugs, a new but expanding class, the so-called virulence-arresting drugs, targeting the inhibition of virulence factor production rather than kill pathogens, has emerged. These drugs can restore or augment the antibiotics' effect in a pathogen-specific manner, thus decreasing the risk of resistance and side effects [59-62].

We have previously demonstrated the effects of some natural pure compounds or products (probiotic fractions, essential oils, bacteriophages, etc.) on the phenotypic or genotypic expression of virulence factors in opportunistic pathogens [32,63-65].

In the present study, the tested EOs inhibited the expression of the analyzed soluble virulence factors by different degrees, their efficiency being similar to that of the pure compounds. The most inhibited virulence factors in S. aureus were haemolysins, followed by siderophore-like compounds and lecithinase, while in P. aeruginosa, DN-ase, siderophorelike and haemolysins (Table 4). 
Table 4. The number of strains in which the inhibition of at least one virulence factor expression was noticed in the presence of the EOs and of their major compounds.

\begin{tabular}{|c|c|c|c|c|c|c|c|c|c|}
\hline & Borneol & Camfor & 1,8-Cineole & Limonene & $\alpha$-Pinene & $P a^{\text {a }}$ & $L d^{\mathrm{a}}$ & $P m^{a}$ & $P n^{a}$ \\
\hline \multicolumn{10}{|c|}{ S. aureus } \\
\hline Total no. of strains & 10 & 10 & 10 & 10 & 10 & 10 & 10 & 10 & 10 \\
\hline DN-ase & 1 & 1 & 1 & 1 & 1 & 1 & 1 & 1 & 1 \\
\hline Lipase & 1 & 1 & 2 & 1 & 2 & 1 & 1 & 1 & 1 \\
\hline Lecithinase & 3 & 3 & 4 & 3 & 3 & 5 & 5 & 3 & 5 \\
\hline Haemolysins & 8 & 8 & 9 & 9 & 9 & 9 & 9 & 9 & 9 \\
\hline Caseinase & 3 & 3 & 3 & 3 & 4 & 5 & 3 & 3 & 3 \\
\hline Siderophore-like & 5 & 5 & 7 & 7 & 8 & 7 & 6 & 5 & 6 \\
\hline \multicolumn{10}{|c|}{ P. aeruginosa } \\
\hline Total no. of strains & 10 & 10 & 10 & 10 & 10 & 10 & 10 & 10 & 10 \\
\hline DN-ase & 10 & 9 & 10 & 9 & 10 & 10 & 10 & 10 & 9 \\
\hline Lipase & 5 & 6 & 6 & 5 & 5 & 6 & 5 & 6 & 6 \\
\hline Lecithinase & 4 & 5 & 5 & 5 & 6 & 6 & 6 & 5 & 5 \\
\hline Haemolysins & 6 & 7 & 6 & 7 & 7 & 6 & 6 & 6 & 6 \\
\hline Caseinase & 9 & 9 & 8 & 9 & 0 & 0 & 0 & 0 & 0 \\
\hline Siderophore-like & 10 & 7 & 10 & 10 & 10 & 10 & 10 & 10 & 10 \\
\hline
\end{tabular}

a Pa: P. abies; Ld: L. decidua; Pm: P. menziesii; Pn: P. nigra.

\section{Materials and Methods}

\subsection{Reagents and Solvents}

SupraSolv dichloromethane was used for the gas chromatography, anhydrous $\mathrm{Na}_{2} \mathrm{SO}_{4}$ granulated for organic trace analysis, and the pure compounds (Ph. Eur.) — $\alpha$-pinene, (+)limonene, phellandrene, eucalyptol, borneol, camphor and nerolidol—were purchased from Merck, Darmstadt, Germany. The n-alkanes $\mathrm{C}_{8}-\mathrm{C}_{24}$ used for the determination of the Kovats retention indices were from Fluka, Switzerland.

\subsection{Plant Material}

The samples of young shoots with needles (around $1000 \mathrm{~g}$ ) of Douglas fir (P. menziesii), European larch (L. decidua ssp. Carpathica), Norway spruce (P. abies) and black pine (P. nigra ssp. nigra) were collected from an intensive plantation located in the tree nursery of the "Marin Drăcea" National Institute for Forestry Research and Development (Voluntari, Romania). The plants grew in natural vegetation conditions, without the use of chemical fertilizers or pesticides to control weeds, diseases and pests. For each species, the samples were harvested from ten individual 6-8-year-old trees. The samples were dried, separated from branches and manually grounded.

\subsection{Essential Oil Extraction}

The needles ( $50 \mathrm{~g}$ ) were hydro-distilled in a Clevenger-type apparatus for $4 \mathrm{~h}$ [66]. The EOs was dried over anhydrous $\mathrm{Na}_{2} \mathrm{SO}_{4}$, stored in a dark glass bottle and kept at $4{ }^{\circ} \mathrm{C}$ until analysis. The oil samples were diluted in dichloromethane $(1 / 200)$ and $1 \mu \mathrm{L}$ was injected for GC analysis.

\subsection{Gas Chromatography-Mass Spectrometry}

GC-MS analysis of the EOs was carried out using a Fisons Instruments GC 8000 with an electron impact quadrupole, MD 800 mass spectrometer detector.

The electron ionization energy was $70 \mathrm{eV}$. A fused silica column of $5 \%$ phenylpoly (dimethylsiloxane) (SLB-5 ms, $30 \mathrm{~m} \times 0.32 \mathrm{~mm}$ i.d., film thickness $=0.25 \mu \mathrm{m}$ ) was employed The operating conditions were as follows: a split-splitless injector (split ratio, 1:30) at $280{ }^{\circ} \mathrm{C}$, ion-source temperature $200{ }^{\circ} \mathrm{C}$ and the interface temperature $280^{\circ} \mathrm{C}$; initial column temperature, $40^{\circ} \mathrm{C}$ for $3 \mathrm{~min}$, raised at $4{ }^{\circ} \mathrm{C} / \mathrm{min}$ to $280{ }^{\circ} \mathrm{C}$ and finally held isothermally for $20 \mathrm{~min}$; the carrier gas (helium) flow rate was $2 \mathrm{~mL} / \mathrm{min}$; and sample volume injected, $1 \mu \mathrm{L}$. 
Data acquisition was performed with MassLab 3.4 Software for the mass range 30-600 u with a scan speed of $1 \mathrm{scan} / \mathrm{s}$. The identity of the EO components was established from their GC Kovats retention indices and from mass spectra by computer matching with a mass spectra library (NIST, Wiley and a personal library of 600 spectra). The Kovats retention indices were determined in relation to a homologous series of n-alkanes $\left(C_{8}-C_{24}\right)$ and compared with those reported in the literature [67-69]. The components' relative concentrations were calculated from the GC peaks without using correction factors.

\subsection{Antimicrobial Activity}

\subsubsection{Microbial Strains}

The antimicrobial and anti-biofilm activity was tested on Gram-positive (Staphylococcus aureus ATCC 25923, Bacillus subtilis 6633, Enterococcus faecalis ATCC 29212) and Gram-negative (Escherichia coli ATCC 25922, Pseudomonas aeruginosa ATCC 27853) bacterial as well as fungal (Candida albicans ATCC 10231) reference strains, but also on S. aureus and P. eruginosa strains isolated from hospitalized patients. S. aureus $19 \mathrm{~F}$, S. aureus $8 \mathrm{~V}$ and $S$. aureus $35 \mathrm{PL}$ were isolated from pharyngeal exudates, vaginal swabs and wound secretions, respectively; S. aureus $12 \mathrm{H}$ and P. aeruginosa $1 \mathrm{H}$ from blood cultures; and P. aeruginosa 61/2, P. aeruginosa 399 and P. aeruginosa 261/1 from urine cultures.

\subsubsection{Qualitative Assessment}

The antimicrobial activity was determined by an adapted diffusion method. Briefly, the microbial inoculum with a density corresponding to $0.5 / 1 \mathrm{McF}$ arland standard for bacterial/fungal strains was evenly swabbed on the agar surface in three directions, and thereafter, $10 \mu \mathrm{L}$ of the stock solution of EO: DMSO was spotted on the seeded medium.

\subsubsection{Quantitative Analysis}

Serial microdilution method in liquid medium using 96-well plates was performed, the intensity of bacterial growth being appreciated by the absorbance value read spectrophotometrically at $620 \mathrm{~nm}$; the MIC $(\mu \mathrm{L} / \mathrm{mL})$ was determined as the last concentration at which no microbial growth was observed [70].

\subsubsection{The Microbial Adherence Capacity to the Inert Substratum}

The slime test was used to highlight the EOs influence on the microbial adherence capacity to the inert substratum represented by the polymeric material of the 96 multiwell plates. Following the quantitative analysis of the antimicrobial effect, the adhered biomass was fixed with methanol, stained with violet crystal, resuspended in $33 \%$ acetic acid solution and assessed spectrophotometrically at $490 \mathrm{~nm}$ [71].

\subsubsection{The Influence of EOs on the QS Genes Expression}

The effects of the EOs and limonene (EO or limonene: DMSO, 1:1, v/v) on QS gene expression in $P$. aeruginosa were investigated by real-time reverse transcriptase quantitative PCR (RT-qPCR), using a commercial kit (GeneJet RNA Purification Kit Fermentas), following the manufacturer's indications. Total RNA was extracted overnight from P. aeruginosa bacterial cultures treated and untreated with EOs. All the details about this experimental part were previously published [32,63].

\subsubsection{The Synergistic Activity with Antibiotics}

The antibiotic susceptibility of the $S$. aureus and P. aeruginosa strains was tested by the disk-diffusion method (Kirby-Bauer), according to the CLSI recommendations. The standardized bacterial suspensions were seeded onto a solid medium (Mueller-Hinton agar), as described for the qualitative screening. Two replicate plates were prepared for each strain [72]. For establishing the EOs' influence on the antibiotic susceptibility, $10 \mu \mathrm{L}$ of each EO stock solution (essential oil: DMSO 1:1, v/v) were placed on each antibiotic disk, with one replicate per strain. Plates were incubated for $16-18 \mathrm{~h}$ at $35 \pm 2{ }^{\circ} \mathrm{C}$. The results 
were read by measuring the diameter of the inhibition zones by using a hand-held caliper with a ruler, as generated by the different antibiotics comparatively to the antibiotics-EOs solution combination.

\subsection{The Soluble Enzymatic Virulence Factors}

The microbial strains were cultivated in liquid medium (nutrient broth) with and without the addition of subinhibitory concentrations of the tested EOs stock solution. The obtained overnight bacterial cultures were spotted onto special media for assessing the following virulence factors production $[70,73]$.

Plate haemolysis: the strains were streaked on blood Sabouraud agar plates containing $5 \%(v / v)$ sheep blood in order to obtain isolated colonies. After incubation at $37^{\circ} \mathrm{C}$ for $24 \mathrm{~h}$ the clear zone (total lysis of the red blood cells) around the colonies was registered as positive reaction.

Gelatinase activity: determined by using 3\% gelatine agar as substrate medium. After incubation at $37^{\circ} \mathrm{C}$ up to $48 \mathrm{~h}$, a clear zone surrounding the growth area indicated gelatine proteolysis (gelatinase presence).

Caseinase activity: determined using $15 \%$ soluble casein agar as substrate. The strains were spotted and after incubation at $37^{\circ} \mathrm{C}$ for $24 \mathrm{~h}$, a precipitation zone surrounding the bacteria growth indicated the casein production.

DNA-se production: studied using DNA agar medium. The strains were spotted and after incubation at $37^{\circ} \mathrm{C}$ for $24 \mathrm{~h}$, a drop of $\mathrm{HCl} 1 \mathrm{~N}$ solution was added upon the spotted cultures; a clearing zone around the culture was interpreted as positive reaction.

Lipase production: the cultures were spotted on Tween 80 agar with a substrate at a final concentration of $1 \%$ and were incubated at $37{ }^{\circ} \mathrm{C}$ up to 7 days. An opaque (precipitation) zone around the spot was registered as positive reaction.

Lecithinase production: the cultures were spotted into $2.5 \%$ yolk agar and were incubated at $37^{\circ} \mathrm{C}$ for 7 days. An opaque (precipitation) zone around the spot indicated the lecithinase production.

\subsection{Statistical Analysis}

All experiments were done in triplicate, but the MIC and MBEC had the same values, so they were not expressed as the mean $\pm \mathrm{SD}$. The results obtained were represented by the last concentration at which no microbial growth was observed. The statistical impact of the EOs on microbial type (Gram-positive and Gram-negative) highlighted whether the antimicrobial effect is significant on the microorganism classes. The statistical analysis was performed using GraphPad Prism v9 (paired t-test). A $p$ value $<0.05$ was considered statistically significant. Significance values for antimicrobial activity against Gram-positive and Gram-negative strains are shown as ${ }^{* * *} p<0.001$.

\section{Conclusions}

Our study revealed that the EOs extracted from the coniferous species L. decidua, P. nigra, P. abies and P. menziesii exhibited significant antimicrobial features, in many cases equal or superior to those obtained for the major compounds, demonstrating the synergistic effect of the active compounds found in the EOs. They inhibited the microbial growth of a large number of reference and clinical and resistant $P$. aeruginosa and $S$. aureus strains as well as of the reference C. albicans strain, with MIC values varying from 6.25 to $100 \mu \mathrm{L} / \mathrm{mL}$ and the most susceptible strains being the Gram-positive and fungal ones. The most intensive and broad-spectrum microbicidal effect was exhibited by the P. nigra EOs. A synergistic effect with some antibiotics recommended to be tested against $S$. aureus strains (i.e., oxacillin, tetracycline, erythromycin and gentamycin) was also observed.

The subinhibitory concentrations of the tested EOs inhibited the adherence and the expression of the soluble virulence factors and modulated the QS genes' expression in P. aeruginosa. All these features make the tested EOs promising leads for the development of novel antimicrobial strategies. 
Supplementary Materials: The following are available online at https: / www.mdpi.com/article/ 10.3390/ph14111159/s1, Figure S1. Chromatogram of the Larix decidua essential oil. Figure S2. Chromatogram of the Pseudotsuga menziesii essential oil. Figure S3. Chromatogram of the Pinus nigra volatile essential oil.

Author Contributions: Conceptualization, V.R., methodology, V.R., E.O. and C.S., formal analysis, I.C.M.; investigation, D.-C.V., I.V., I.-A.B., V.R., E.O., C.S., A.I.C. and I.C.M.; resources, I.V. and I.-A.B.; data curation, D.-C.V. and E.O.; writing-original draft preparation, V.R., D.-C.V. and E.O.; writingreview and editing, E.O., I.C.M. and M.C.C.; visualization, E.O., I.C.M., C.S. and M.C.C.; supervision, E.O. and M.C.C. All authors have read and agreed to the published version of the manuscript.

Funding: This research was funded by O.I.M., research project ICUB 20968/30.12.2020 and CNFISFDI-2021-0405.

Institutional Review Board Statement: Not applicable.

Informed Consent Statement: Not applicable.

Data Availability Statement: Data is contained within the article or supplementary material.

Conflicts of Interest: The authors declare no conflict of interest.

\section{References}

1. Bakkali, F.; Averbeck, S.; Averbeck, D.; Idaomar, M. Biological effects of essential oils-A review. Food Chem. Toxicol. 2008, 46, 446-475. [CrossRef]

2. Tajkarimi, M.M.; Ibrahim, S.A.; Cliver, D.O. Antimicrobial herb and spice compounds in food. Food Control 2010, 21, 1199-1218. [CrossRef]

3. Schnitzler, P.; Astani, A.; Reichling, J. Screening for antiviral activities of isolated compounds from essential oils. Evid.-Based Complement. Altern. Med. 2011, 2011, 253643. [CrossRef]

4. Silva, F.; Ferreira, S.; Duarte, A.; Mendonça, D.I.; Domingues, F.C. Antifungal activity of Coriandrum sativum essential oil, its mode of action against Candida species and potential synergism with amphotericin B. Phytomedicine 2011, 19, 42-47. [CrossRef] [PubMed]

5. Schuldt, T.; Dommerich, S.; Pau, H.-W.; Kramp, B. Die mikrobiologische Oberflächenbesiedlung verschiedener Stimmprothesenarten in der Zeitkinetik. Laryngo-Rhino-Otologie 2010, 89, 606-611. [CrossRef]

6. LaSarre, B.; Federle, M.J. Exploiting Quorum Sensing To Confuse Bacterial Pathogens. Microbiol. Mol. Biol. Rev. 2013, 77, 73-111. [CrossRef]

7. Milutinović, M.; Dimitrijević-Branković, S.; Rajilić-Stojanović, M. Plant Extracts Rich in Polyphenols as Potent Modulators in the Growth of Probiotic and Pathogenic Intestinal Microorganisms. Front Nutr. 2021, 30, 688843. [CrossRef]

8. Biradar, B.; Devi, P. Quorum sensing in plaque biofilms: Challenges and future prospects. J. Contemp. Dent. Pract. 2011, 12, 479-485. [CrossRef]

9. Marinas, I.C.; Oprea, E.; Buleandra, M.; Badea, I.A.; Tihauan, B.M.; Marutescu, L.; Angheloiu, M.; Matei, E.; Chifiriuc, M.C. Chemical Composition, Antipathogenic and Cytotoxic Activity of the Essential Oil Extracted from Amorpha fruticosa Fruits. Molecules 2021, 26, 3146. [CrossRef]

10. Bhardwaj, K.; Islam, M.T.; Jayasena, V.; Sharma, B.; Sharma, S.; Sharma, P.; Kuča, K.; Bhardwaj, P. Review on essential oils, chemical composition, extraction, and utilization of some conifers in Northwestern Himalayas. Phyther. Res. 2020, 34, 2889-2910. [CrossRef]

11. Radulescu, V.; Saviuc, C.; Chifiriuc, C.; Oprea, E.; Ilies, D.C.; Marutescu, L.; Lazar, V. Chemical Composition and Antimicrobial Activity of Essential Oil from Shoots Spruce (Picea abies L). Rev. Chim. 2011, 62, 69-74. [CrossRef]

12. Holubová, V.; Hrdlička, P.; Kubáň, V. Age and space distributions of monoterpenes in fresh needles of Picea abies (L) Karst. determined by gas chromatography-mass spectrometry. Phytochem. Anal. 2001, 12, 243-249. [CrossRef] [PubMed]

13. Kupcinskiene, E.; Stikliene, A.; Judzentiene, A. The essential oil qualitative and quantitative composition in the needles of Pinus sylvestris L. growing along industrial transects. Environ. Pollut. 2008, 155, 481-491. [CrossRef] [PubMed]

14. Turtola, S.; Sallas, L.; Holopainen, J.K.; Julkunen-Tiitto, R.; Kainulainen, P. Long-term exposure to enhanced UV-B radiation has no significant effects on growth or secondary compounds of outdoor-grown Scots pine and Norway spruce seedlings. Environ. Pollut. 2006, 144, 166-171. [CrossRef]

15. Judžentienè, A.; Sližytè, J.; Stiklienè, A.; Kupčinskiene, E. Characteristics of essential oil composition in the needles of young Scots pine (Pinus sylvestris L.) stands growing along an aerial ammonia gradient. Chemija 2006, 17, 67-73.

16. Lee, J.-H. Comparison of Chemical Compositions and Antimicrobial Activities of Essential Oils from Three Conifer Trees; Pinus densiflora, Cryptomeria japonica, and Chamaecyparis obtusa. J. Microbiol. Biotechnol. 2009, 19, 391-396. [CrossRef] [PubMed]

17. Metsämuuronen, S.; Siren, H. Antibacterial Compounds in Predominant Trees in Finland: Review. J. Bioprocess. Biotech. $2014,4,1$. [CrossRef] 
18. Snieškienè, V.; Stankevičienè, A.; Varkulevičienė, J. The Effect of The Essential Oils on Micromycetes Isolated from Plants. Zemdirb. Agric. Kèdainiu Raj. Liet. Zemdirb. Inst. 2008, 95, 447-452.

19. Krauze-Baranowska, M.; Mardarowicz, M.; Wiwart, M.; Pobłocka, L.; Dynowska, M. Antifungal Activity of the Essential Oils from Some Species of the Genus Pinus. Z. Naturforsch. C 2002, 57, 478-482. [CrossRef]

20. Tesevic, V.; Milosavljevic, S.; Vajs, V.; Djordjevic, I.; Sokovic, M.; Lavadinovic, V.; Novakovic, M. Chemical composition and antifungal activity of the essential oil of Douglas fir (Pseudosuga menziesii mirb. Franco) from Serbia. J. Serb. Chem. Soc. 2009, 74, 1035-1040. [CrossRef]

21. Politeo, O. Chemical composition and evaluation of acetylcholinesterase inhibition and antioxidant activity of essential oil from Dalmatian endemic species Pinus nigra Arnold ssp. dalmatica (Vis.) Franco. J. Med. Plants Res. 2011, 5, 6590-6596. [CrossRef]

22. Yang, X.; Zhao, H.; Wang, J.; Meng, Q.; Zhang, H.; Yao, L.; Zhang, Y.; Dong, A.; Ma, Y.; Wang, Z.; et al. Chemical Composition And Antioxidant Activity Of Essential Oil Of Pine Cones Of Pinus Armandii From The Southwest Region of China. J. Med. Plants Res. 2010, 4, 1668-1672. [CrossRef]

23. K1lıç, Ö.; Kocak, A. Essential oil composition of six Pinus L. taxa (Pinaceae) from Canada and their chemotaxonomy. J. Agric. Sci. Technol. 2014, 4, 67-73.

24. Nikolić, B.; Ristić, M.; Bojović, S.; Marin, P.D. Variability of the Needle Essential Oils of Pinus heldreichii from Different Populations in Montenegro and Serbia. Chem. Biodivers. 2007, 4, 905-916. [CrossRef]

25. Dob, T.; Berramdane, T.; Dahmane, D.; Chelghoum, C. Chemical Composition of the Needles Oil of Pinus canariensis from Algeria. Chem. Nat. Compd. 2005, 41, 165-167. [CrossRef]

26. Almaarri, K.; Alamir, L.; Junaid, Y.; Xie, D.-Y. Volatile compounds from leaf extracts of Juniperus excelsa growing in Syria via gas chromatography mass spectrometry. Anal. Methods 2010, 2, 673. [CrossRef]

27. Tumen, I.; Hafizoglu, H.; Kilic, A.; Dönmez, I.E.; Sivrikaya, H.; Reunanen, M. Yields and Constituents of Essential Oil from Cones of Pinaceae spp. Natively Grown in Turkey. Molecules 2010, 15, 5797-5806. [CrossRef] [PubMed]

28. Dayisoylu, K.S.; Alma, M.H. Chemical analysis of essential oils from cone's rosin of Cilician fir (Abies cilicica subsp. cilicica). Afr. J. Biotechnol. 2009, 8, 3502-3505. [CrossRef]

29. Duquesnoy, E.; Castola, V.; Casanova, J. Composition and chemical variability of the twig oil of Abies alba Miller from Corsica. Flavour Fragr. J. 2007, 22, 293-299. [CrossRef]

30. Amri, I.; Hanana, M.; Jamoussi, B.; Hamrouni, L. Essential oils of Pinus nigra J.F. Arnold subsp. laricio Maire: Chemical composition and study of their herbicidal potential. Arab. J. Chem. 2017, 10, S3877-S3882. [CrossRef]

31. Rădulescu, V.; Ilies, D.C.; Voiculescu, I.; Biris, I.A.; Craciunescu, A. Determination of ascorbic acid in shoots from different coniferous species by HPLC. Farmacia 2013, 61, 1158-1166.

32. Saviuc, C.; Cotar, A.I.; Holban, A.M.; Banu, O.; Grumezescu, A.M.; Carmen Chifiriuc, M. Phenotypic and molecular evaluation of Pseudomonas aeruginosa and Staphylococcus aureus virulence patterns in the presence of some essential oils and their major compounds. Lett. Appl. NanoBioSci 2013, 2, 91-96.

33. Awadh Ali, N.A.; Wurster, M.; Arnold, N.; Teichert, A.; Schmidt, J.; Lindequist, U.; Wessjohan, L. Chemical Composition and Biological Activities of Essential Oils from the Oleogum Resins of Three Endemic Soqotraen Boswellia Species. Rec. Nat. Prod. 2008, 2, 6-12.

34. Garcia, G.; Garcia, A.; Gibernau, M.; Bighelli, A.; Tomi, F. Chemical compositions of essential oils of five introduced conifers in Corsica. Nat. Prod. Res. 2017, 31, 1697-1703. [CrossRef] [PubMed]

35. Mofikoya, O.O.; Mäkinen, M.; Jänis, J. Chemical Fingerprinting of Conifer Needle Essential Oils and Solvent Extracts by UltrahighResolution Fourier Transform Ion Cyclotron Resonance Mass Spectrometry. ACS Omega 2020, 5, 10543-10552. [CrossRef] [PubMed]

36. Runyoro, D.; Ngassapa, O.; Vagionas, K.; Aligiannis, N.; Graikou, K.; Chinou, I. Chemical composition and antimicrobial activity of the essential oils of four Ocimum species growing in Tanzania. Food Chem. 2010, 119, 311-316. [CrossRef]

37. Andrews, R.E.; Parks, L.W.; Spence, K.D. Some effects of Douglas fir terpenes on certain microorganisms. Appl. Environ. Microbiol. 1980, 40, 301-304. [CrossRef]

38. Uribe, S.; Ramirez, J.; Pena, A. on Yeast Membrane Functions. Yeast 1985, 161, 1195-1200.

39. Helander, I.M.; Alakomi, H.L.; Latva-Kala, K.; Mattila-Sandholm, T.; Pol, I.; Smid, E.J.; Gorris, L.G.M.; Von Wright, A. Characterization of the Action of Selected Essential Oil Components on Gram-Negative Bacteria. J. Agric. Food Chem. 1998, 46, $3590-3595$. [CrossRef]

40. Magwa, M.L.; Gundidza, M.; Gweru, N.; Humphrey, G. Chemical composition and biological activities of essential oil from the leaves of Sesuvium portulacastrum. J. Ethnopharmacol. 2006, 103, 85-89. [CrossRef]

41. Filipowicz, N.; Kaminski, M.; Kurlenda, J.; Asztemborska, M.; Ochocka, J.R. Antibacterial and antifungal activity of juniper berry oil and its selected components. Phyther. Res. 2003, 17, 227-231. [CrossRef]

42. Chifiriuc, M.C.; Banu, O.; Bleotu, C.; Lazăr, V. Interaction of bacteria isolated from clinical biofilms with cardiovascular prosthetic devices and eukaryotic cells. Anaerobe 2011, 17, 419-421. [CrossRef] [PubMed]

43. Lazar, V.; Holban, A.M.; Curutiu, C.; Chifiriuc, M.C. Modulation of Quorum Sensing and Biofilms in Less Investigated GramNegative ESKAPE Pathogens. Front. Microbiol. 2021, 12, 676510. [CrossRef] [PubMed] 
44. Bilcu, M.; Grumezescu, A.M.; Oprea, A.E.; Popescu, R.C.; Mogoșanu, G.D.; Hristu, R.; Stanciu, G.A.; Mihailescu, D.F.; Lazar, V.; Bezirtzoglou, E.; et al. Efficiency of Vanilla, Patchouli and Ylang Ylang Essential Oils Stabilized by Iron Oxide@C14 Nanostructures against Bacterial Adherence and Biofilms Formed by Staphylococcus aureus and Klebsiella pneumoniae Clinical Strains. Molecules 2014, 19, 17943-17956. [CrossRef] [PubMed]

45. Ciubuca, B.-M.; Saviuc, C.-M.; Chifiriuc, M.-C.; Lazar, V. Microbial Resistance to Natural Compounds: Challenges for Developing Novel Alternatives to Antibiotics. Curr. Org. Chem. 2016, 20, 2983-2988. [CrossRef]

46. Kovač, J.; Šimunović, K.; Wu, Z.; Klančnik, A.; Bucar, F.; Zhang, Q.; Možina, S.S. Antibiotic Resistance Modulation and Modes of Action of (-)- $\alpha$-Pinene in Campylobacter jejuni. PLoS ONE 2015, 10, e0122871. [CrossRef]

47. Ayaz, M.; Ullah, F.; Sadiq, A.; Ullah, F.; Ovais, M.; Ahmed, J.; Devkota, H.P. Synergistic interactions of phytochemicals with antimicrobial agents: Potential strategy to counteract drug resistance. Chem. Biol. Interact. 2019, 308, 294-303. [CrossRef]

48. Eleraky, N.E.; Allam, A.; Hassan, S.B.; Omar, M.M. Nanomedicine Fight against Antibacterial Resistance: An Overview of the Recent Pharmaceutical Innovations. Pharmaceutics 2020, 12, 142. [CrossRef]

49. Miladinović, D.L.; Ilić, B.S.; Kocić, B.D.; Marković, M.S.; Miladinović, L.C. In Vitro Trials of Dittrichia graveolens Essential Oil Combined with Antibiotics. Nat. Prod. Commun. 2016, 11, 865-868. [CrossRef]

50. Sobieszczańska, N.; Myszka, K.; Szwengiel, A.; Majcher, M.; Grygier, A.; Wolko, Ł. Tarragon essential oil as a source of bioactive compounds with anti-quorum sensing and anti-proteolytic activity against Pseudomonas spp. isolated from fish-In vitro, in silico and in situ approaches. Int. J. Food Microbiol. 2020, 331, 108732. [CrossRef]

51. Lu, L.; Li, M.; Yi, G.; Liao, L.; Cheng, Q.; Zhu, J.; Zhang, B.; Wang, Y.; Chen, Y.; Zeng, M. Screening Strategies for Quorum Sensing Inhibitors in Combating Bacterial Infection. J. Pharm. Anal. 2021, 1-31. [CrossRef]

52. Luciardi, M.C.; Blázquez, M.A.; Alberto, M.R.; Cartagena, E.; Arena, M.E. Lemon oils attenuate the pathogenicity of pseudomonas aeruginosa by quorum sensing inhibition. Molecules 2021, 26, 2863. [CrossRef]

53. Baban Zadeh, P.; Khaledi, A.; Esmaeili, D. Satureja khuzestanica essential oil against quorum sensing of pseudomonas aeroginosa using RT-PCR. Iran. J. Public Health 2019, 48, 1390-1391. [CrossRef]

54. Li, W.R.; Ma, Y.K.; Xie, X.B.; Shi, Q.S.; Wen, X.; Sun, T.L.; Peng, H. Diallyl disulfide from garlic oil inhibits Pseudomonas aeruginosa quorum sensing systems and corresponding virulence factors. Front. Microbiol. 2019, 10, 3222. [CrossRef] [PubMed]

55. Lou, Z.; Letsididi, K.S.; Yu, F.; Pei, Z.; Wang, H.; Letsididi, A.R. Inhibitive effect of eugenol and its nanoemulsion on quorum sensing-mediated virulence factors and biofilm formation by Pseudomonas aeruginosa. J. Food Prot. 2019, 82, 379-389. [CrossRef]

56. Kumar, L.; Chhibber, S.; Kumar, R.; Kumar, M.; Harjai, K. Zingerone silences quorum sensing and attenuates virulence of Pseudomonas aeruginosa. Fitoterapia 2015, 102, 84-95. [CrossRef]

57. Kostylev, M.; Kim, D.Y.; Smalley, N.E.; Salukhe, I.; Peter Greenberg, E.; Dandekar, A.A. Evolution of the Pseudomonas aeruginosa quorum-sensing hierarchy. Proc. Natl. Acad. Sci. USA 2019, 116, 7027-7032. [CrossRef] [PubMed]

58. Jack, A.A.; Khan, S.; Powell, L.C.; Pritchard, M.F.; Beck, K.; Sadh, H.; Sutton, L.; Cavaliere, A.; Florance, H.; Rye, P.D.; et al. Alginate Oligosaccharide-Induced Modification of the lasI-lasR and rhlI-rhlR Quorum-Sensing Systems in Pseudomonas aeruginosa. Antimicrob. Agents Chemother. 2018, 62, e02318-17. [CrossRef]

59. Dickey, S.; Cheung, G.; Otto, M. Different drugs for bad bugs: Antivirulence strategies in the age of antibiotic resistance. Nat. Rev. Drug Discov. 2017, 16, 457-471. [CrossRef]

60. Allen, R.C.; Popat, R.; Diggle, S.P.; Brown, S.P. Targeting virulence: Can we make evolution-proof drugs? Nat. Rev. Microbiol. 2014, 12, 300-308. [CrossRef] [PubMed]

61. Rasko, D.A.; Sperandio, V. Anti-virulence strategies to combat bacteria-mediated disease. Nat. Rev. Drug Discov. 2010, 9, 117-128. [CrossRef] [PubMed]

62. Sintchenko, V.; Timms, V.; Sim, E.; Rockett, R.; Bachmann, N.; O'Sullivan, M.; Marais, B. Microbial Genomics as a Catalyst for Targeted Antivirulence Therapeutics. Front. Med. 2021, 8, 641260. [CrossRef] [PubMed]

63. Cotar, A.I.; Chifiriuc, M.C.; Dinu, S.; Pelinescu, D.; Banu, O.; Lazăr, V. Quantitative real-time PCR study of the influence of probiotic culture soluble fraction on the expression of Pseudomonas aeruginosa quorum sensing genes. Roum. Arch. Microbiol. Immunol. 2010, 69, 213-223.

64. Neguţ, A.C.; Chifiriuc, M.C.; Săndulescu, O.; Streinu-Cercel, A.; Oprea, M.; Drăgulescu, E.C.; Gheorghe, I.; Berciu, I.; Coralia, B.; Popa, M.; et al. Bacteriophage-driven inhibition of biofilm formation in Staphylococcus strains from patients attending a Romanian reference center for infectious diseases. FEMS Microbiol. Lett. 2016, 363, 193. [CrossRef] [PubMed]

65. Marinas, I.C.; Oprea, E.; Chifiriuc, M.C.; Badea, I.A.; Buleandra, M.; Lazar, V. Chemical Composition and Antipathogenic Activity of Artemisia annua Essential Oil from Romania. Chem. Biodivers. 2015, 12, 1554-1564. [CrossRef]

66. Commission National Medicines Agency. Romanian Pharmacopoeia, 10th ed.; Medical Publishing: Bucharest, Romania, 1993.

67. Adams, R.P. Identification of Essential Oils by Ion Trap Mass Spectroscopy; Academic Press: London, UK, 1996.

68. Acree, T.E.; Arn, H. Flavornet and Human Odor Space. Available online: www.flavornet.org (accessed on 11 April 2021).

69. El-Saed, A.M. The Pherobase: Datebase of Pheromones and Semiochemicals. 2019. Available online: www.pherobase.org (accessed on 11 April 2021).

70. Lazar, V.; Balotescu, M.C.; Moldovan, L.; Vasilescu, G.; Petrache, L.M.; Bulai, D.; Cernat, R.C. Comparative evaluation of qualitative and quantitative methods used in the study of antifungal and antibacterial activity of hydroalcoholic vegetal extracts. Rom. Biotechnol. Lett. 2005, 10, 2225-2232. 
71. Norouzi, F.; Mansouri, S.; Moradi, M. Comparison of cell surface hydrophobicity and biofilm formation among ESBL-and nonESBL-producing Pseudomonas aeruginosa clinical isolates. Afr. J. Microbiol. Res. 2010, 4, 1143-1147.

72. Grădinaru, A.C.; Trifan, A.; Şpac, A.; Brebu, M.; Miron, A.; Aprotosoaie, A.C. Antibacterial activity of traditional spices against lower respiratory tract pathogens: Combinatorial effects of Trachyspermum ammi essential oil with conventional antibiotics. Lett. Appl. Microbiol. 2018, 67, 449-457. [CrossRef]

73. Georgescu, M.; Gheorghe, I.; Curutiu, C.; Lazar, V.; Bleotu, C.; Chifiriuc, M.C. Virulence and resistance features of Pseudomonas aeruginosa strains isolated from chronic leg ulcers. BMC Infect. Dis. 2016, 16, 92. [CrossRef] 